\title{
A Psychometric Evaluation of a Korean Version of the Quality of Life in Late-Stage Dementia Scale
}

\author{
Jeong, Eunhye ${ }^{1} \cdot$ Park, Min Sun ${ }^{1} \cdot$ Lee, Ye-Na ${ }^{1} \cdot$ Chang, Sung $\mathrm{Ok}^{2}$ \\ ${ }^{1}$ Research Professor, College of Nursing, Korea University, Seoul \\ ${ }^{2}$ Professor, College of Nursing \& BK21 FOUR R\&E Center for Learning Health Systems, Korea University, Seoul, Korea
}

\begin{abstract}
Purpose: This study was conducted to translate and validate a Korean version of the Quality of Life in Late-Stage Dementia (QUALID-K) scale. Methods: A cross-sectional design was applied to culturally adapt and validate the scale. A total of 197 participants from two long-term care hospitals in Korea were recruited. The psychometric properties of the QUALID-K scale, including dimensionality of subscales, concurrent, discriminant, and convergence validity, test-retest reliability, inter-rater reliability, and internal consistency were evaluated. Results: The QUALID-K scale's dimensionality differed from the original one-factor structure, and a three-factor model better fit the data. The validity analysis showed a significant association of the QUALID-K with cognitive function, activities of daily living, depressive symptoms, and pain. Test-retest and inter-rater analysis confirmed the measurement's stability. Conclusion: The QUALID-K scale appears to be a reliable and valid measurement to assess the quality of life for those with severe dementia in the Korean population.
\end{abstract}

Key Words: Aged; Dementia; Long-term care; Validation study; Quality of life

\section{INTRODUCTION}

Dementia is a chronic syndrome characterized by an irreversible decline of cognitive, social, and physical functions and is a leading cause of increased mortality. Globally, the number of people with dementia was estimated at 47.5 million in 2015, with 7.7 million new cases every year [1]. The stage of dementia is diagnosed based on scores on a global scale, such as Mini-Mental State Examination (MMSE) and the threshold for severe dementia of MMSE is generally considered to be 10 or less [2]. Severe dementia is considered a major problem in the public health sphere, since it is always accompanied by frequent mental and behavioral problems. Especially in people with severe dementia, these functional declines inevitably result in a loss of autonomy and lead to a decreased quality of life (QoL) [3]. For this reason, it is important to measure the quality of life of patients with severe dementia.
Improved QoL is considered a major outcome of health interventions in patients in a variety of settings. QoL is defined as an "individual's perceptions of their position in life in the context of the culture and value system in which they live, and in relationship to their goals, expectations, and standards" by the World Health Organization [4]. In the context of people with dementia, Whitehouse et al. defined QoL as "the integration of cognitive functioning, activities of daily living, social interactions and psychological well-being" [5]. These definitions could be applied to mild to moderate dementia, but might be difficult to use concerning severe dementia [6].

In this respect, Lawton developed a four-dimensional theoretical model of QoL in patients with dementia, divided by two criteria: subjective criteria ("psychological well-being" and "perceived QoL") and objective criteria ("behavioral competence" and "objective environment") [7]. Especially for application to patients with severe de-

Corresponding author: Chang, Sung Ok https://orcid.org/0000-0003-2710-4291

College of Nursing, Korea University, 145 Anam-ro, Sungbuk-gu, Seoul 02841, Korea.

Tel: +82-2-3290-4918, Fax: +82-2-9280-9108, E-mail: sungok@korea.ac.kr

Received: Nov 16, 2020 / Revised: Jan 28, 2021 / Accepted: Feb 7, 2021

This is an open access article distributed under the terms of the Creative Commons Attribution Non-Commercial License (http://creativecommons.org/licenses/ by-nc/3.0), which permits unrestricted non-commercial use, distribution, and reproduction in any medium, provided the original work is properly cited. 
mentia, Volicer and Bloom-Charette described a conceptual framework of QoL with three dimensions which are "meaningful activities", "medical issues", and "psychiatric symptoms" [8] .

QoL is usually measured through self-rated questionnaires. Although a proxy measure of QoL can be controversial [6], it is currently accepted as a possible method of evaluating QoL in people with dementia, especially those with severe dementia who have limited cognitive functioning [9]. Previous studies have shown that proxy reports and self-rated QoL are highly correlated to the objective dimensions of Lawton et al.'s theoretical model [7].

The Quality of Life in Late-Stage Dementia (QUALID) scale was developed to measure the objective criteria of Lawton et al.'s definition $[7,10]$. The QUALID scale consists of 11 items of observable behaviors and is applied to a caregiver who has contacted with the patient significantly during the last seven days. The strengths of the scale include that it is the only instrument developed specifically to target late-stage dementia and that it has been evaluated as one of the instruments with the best evidence of validity and reliability [6]. A recent study reported that the QUALID scale is a more appropriate tool for assessing QoL in people with late-stage dementia than EuroQol-5Dimension (EQ-5D), which is one of the QoL scales most used on the general population [11]. Moreover, Black and Rabins reviewed QoL instruments and concluded that the QUALID scale is recommended for patients with severe cognitive impairment [12]. With the increasing need for evaluating a broader range of health in people with dementia, the QUALID scale is frequently used in many studies.

The QUALID scale has been validated in several languages, including English, Spanish, Norwegian, Japanese, Italian, and Czech. However, the scale is currently not available in the Korean language and lacks evidence concerning its factorial structure. Since it is important to adapt and validate scales to other languages for cross-cultural comparisons and providing scientific evidence, this study was conducted to translate the QUALID scale into Korean and assess the psychometric properties of a translated scale.

\section{METHODS}

\section{Aim and Design}

This study was a cross-sectional study aimed at producing the Korean version of the QUALID (QUALID-K) scale and evaluating its psychometric properties.

\section{Setting and Samples}

This study was conducted in two long-term care hospitals in Busan, Korea, from August to November 2019. The required sample size is between 5 to 10 per item of the scale (55 to 110) for exploratory factor analysis and 200 to 400 for confirmatory factor analysis (CFA) by AMOS $[13,14]$. Based on the evidence, a convenience sample of 197 eligible older patients with dementia (60 years or older) was recruited in the study. Initially, patients diagnosed with dementia by a psychiatrist, including all stages of the disease, were enrolled, since when measuring the QoL for patients with dementia in practice, it is more feasible to apply it to all subjects than to only patients with severe dementia separately. The exclusion criteria were as follows: other psychiatric diseases, such as schizophrenia; severely impaired consciousness; and refusal to participate by a patient or a patient's family.

\section{Procedure}

The clinical and demographic data, including age, sex, diagnosis, cognitive functioning, and activities of daily living (ADL) score, were obtained from the patients' medical records. All proxy informants were registered nurses: (1) who had worked in the hospital over three years; and (2) who had received the 60- minute training on the features and usage of the included scales. Nine registered nurses (hospital A: 2, hospital B: 7) who were familiar with the baseline behavior of the patients through regular contact and who could grasp the patients' current condition during recent three out of seven days, were selected as informants.

Prior to translation, permission from the original author of the QUALID scale was obtained. First, a forward translation into Korean was performed by researchers specializing in geriatric nursing under the supervision of three bilingual experts in geriatric nursing, who are professor of nursing. Second, a back translation into English was performed by a researcher who are fluent in both English and Korean who had no information of the questionnaires. Afterwards, the three experts compared the back-translated version and the original version to detect and correct content differences. At this step, the items scored 4 or 5 using a five-point Likert scale for content validity was selected as the final version.

\section{Instruments}

\section{1) Quality of life}


The QUALID scale consists of 11 items, which are scored on a 5-point Likert scale and produce a total score ranging from 11 (best QoL) to 55 (worst QoL). The scale is based on how frequently each item occurs, from "never/ seldom" to "most of the day", in the last seven days. The scale consists of items that mainly rate the non- verbal behavior of patients, such as "smiles", "appears sad" and "facial expression of discomfort" [10].

The Quality of Life for Alzheimer's Disease (QoL-AD) includes 13 items and is developed to evaluate the QoL of people with mild to moderate dementia. The scale has two versions, which are proxy-report and self-report versions. This study applied the proxy-report version, on which individual items are graded from 1 (poor) to 4 (excellent), giving a total score from 13 to 52. A higher score is indicative of a better QoL [15].

\section{2) Cognitive impairment}

To evaluate the level of cognitive impairment, the Korean version of the MMSE (MMSE-K), which was standardized by Park and Kwon, was applied [16,17]. The MMSE is one of the most popular instruments for detection of cognitive impairment, giving a total score from 0 to 30 . A higher score indicates milder cognitive impairment. The total score $0 \sim 19,20 \sim 23$, and 24 30 points are interpreted as definite dementia, questionable dementia, and definite non-dementia, respectively [16]. Since the patients in the recruited hospitals in this study were evaluated twice a year by using MMSE-K, we used the recent data for the analysis.

\section{3) Activities of daily living}

The level of daily functioning was evaluated by the $\mathrm{K}$-ADL scale. The K-ADL scale was developed by the Korean Geriatrics Society with the support of the Ministry of Health and Welfare in 2002. The scale is based on Katz's ADL scale and revised according to the Korean living environment and culture [18]. The K-ADL is a 6-item scale, with each item scored from 0-5 and a total score from 0-30, with a higher score indicative of higher functioning level. Since the patients in the recruited hospitals in this study were evaluated monthly by using K-ADL, we used the data gathered between September 1 and November 15 in 2019, for the analysis.

\section{4) Depressive symptoms}

Using the Cornell Scale for Depression in Dementia (CSDD), the depressive symptoms were assessed. Each item in the test is graded from 0 to 2 , giving a total score of 0 to 38. A higher score indicates more severe depres- sion [19].

\section{5) Pain}

To evaluate pain, the Faces Pain Scale-Revised (FPS-R) was applied. The FPS-R consists of six facial expressions of pain, from no pain (0) to severe pain (10). The scale is usually used for assessing the pain of children or the elderly who have difficulties expressing pain verbally [20].

\section{Data Analysis}

The Statistical Package for Social Sciences (SPSS) 23 and IBM SPSS AMOS 26 (SPSS Inc., Chicago. Ill., USA) were used for data analysis. To evaluate the psychometric properties of the QUALID-K scale, the dimensionality of subscales (principal component analysis [PCA] and CFA), concurrent, discriminant, and convergence validity, internal consistency (Cronbach's $\alpha$ ), test-retest reliability, and inter-rater reliability were evaluated.

We used descriptive statistics to estimate the clinical and demographic data of the patients. The QUALID-K score was calculated in terms of ceiling effect, floor effect, skewness, and kurtosis.

The dimensionality of the items on the QUALID-K scale was tested using PCA with the varimax rotation, the Kaiser-Meyer-Oklin (KMO) test, and Bartlett's test of sphericity. The number of factors was determined by the evaluation of the criterion of eigenvalues above 1 .

CFA was used to evaluate the model fit of the three-factor structure resulting from the PCA compared to the original one-factor structure [10]. The CFA results according to the two different factorial models were compared based on $x^{2} / \mathrm{df}$, goodness-of-fit index (GFI), normed fit index (NFI), standardized root mean square residual (SRMR), root mean square error of approximation (RMSEA) and Akaike information criterion (AIC). The $x^{2} / \mathrm{df}$ values should be less than 3 , the GFI and NFI values should be at least 0.90, while the SRMR and RMSEA should be less than 0.10 and 0.08 , respectively [21,22]. The AIC value allows for the comparison of two different models, with lower AIC values indicating the preferred model [22].

To evaluate the concurrent, discriminant, and convertgence validity, Spearman's correlations for the QUALID$\mathrm{K}$ with the QoL-AD, MMSE, ADL-K, CSDD and FPS-R scales were calculated. This study employed three dimensions of QoL in severe dementia to examine the validity: 1. cognitive function and depressive symptoms for "psychiatric symptoms" dimension; 2 . functional status for basic ADL for "meaningful activity" dimension; and 3. pain for "medical issues" dimension were evaluated, respectively. 
The scales' internal consistency was tested using Cronbach's $\alpha$ coefficient. To examine test-retest reliability, 40 patients were evaluated by two nurses within one week. For inter-rater reliability, it was calculated by having the same nurses reassess the 39 participants within one week after the initial assessment.

\section{Ethical Considerations}

The protocol of this study was approved by the Ethical Committee at the university where the authors work (1040548-KU-IRB-18-22-A-2 (E-A-1)), as a part of the project named "the development of 5 types of the Korean version of the symptoms evaluation for patients with dementia." Patients and their families were informed about their right to withdraw from the study at any time with no negative impact as well as about the research's aim and design before participation. Written informed consent from the participating patients, their families, and the heads and staffs of the hospitals were obtained.

\section{RESULTS}

\section{Patient Characteristics}

The mean age of the study participants was 83.6 years (standard deviation $[S D]=7.39$ ), and $73.1 \%$ were women. The number of patients diagnosed with major diseases and the mean scores of the scales including QUALID-K

Table 1. Patient Characteristics

$(N=197)$

\begin{tabular}{llc}
\hline Variables & Categories & $\begin{array}{c}\mathrm{n}(\%) \text { or } \\
\mathrm{M} \pm \mathrm{SD}\end{array}$ \\
\hline Age (year) & & $83.6 \pm 7.39$ \\
Sex & Male & $53(26.9)$ \\
& Female & $144(73.1)$ \\
Diagnosis & CVA & $38(19.3)$ \\
& Parkinsonism & $11(5.6)$ \\
& Cardiovascular disease & $22(11.2)$ \\
QUALID score & & $28.28 \pm 7.73$ \\
Other scale scores & QoL-AD & $25.46 \pm 5.26$ \\
& MMSE-K & $9.38 \pm 4.18$ \\
& CSDD & $6.85 \pm 4.92$ \\
& K-ADL & $17.10 \pm 2.65$ \\
& FPS-R & $2.36 \pm 1.28$ \\
\hline
\end{tabular}

CSDD=Cornell Scale for Depression in Dementia; $C V A=C e r e b r o v a s c u l a r$ accident; FPS-R=Faces Pain Scale-Revised; K-ADL=Korean Activities of Daily Living scale; MMSE-K=Korean version of the Mini-Mental State Examination; QUALID=Quality of Life in Late-stage Dementia scale; QoL-AD=Quality of Life for Alzheimer's Disease; $\mathrm{SD}=\mathrm{Standard}$ deviation. scale are presented in Table 1.

\section{Distribution of QUALID-K scores}

The mean QUALID-K score was 28.28 (SD=7.73), and the median score was 28 with a range of 14 to 53 . The skewness and kurtosis of the QUALID-K scores were 0.36 and 0.04 , respectively, without ceiling $(0.0 \%)$ and floor effects $(0.0 \%)$.

\section{Dimensionality}

As a result of the PCA, Bartlett's test of sphericity was $p<.001$ and the KMO measure was 0.801 , which confirmed that the data were appropriate for conducting a PCA. Table 2 shows the results of the PCA with varimax rotation. Three factors were extracted from the QUALID-K scale, which accounted for a total of $64.9 \%$. The three factors were "discomfort" (items 4, 5, 6, 7 and 11), "social interaction" (items 1, 9 and 10) and "depression"(items 2, 3 and 8). Cronbach's $\alpha$ coefficients were higher than .70 for factors 1 and 2, which indicates the level of internal consistency is acceptable.

By using CFA, the degree of model fit was compared. The three-factor model could be slightly improved by setting covariance paths between the errors, e2 e3, e3 e4 and e5 e8. Compared to the Weiner et al.'s original onefactor model [10], the three-factor model had a better fit $\left(x^{2} / \mathrm{dF}=7.12\right.$ vs $1.75, \mathrm{GFI}=0.77$ vs $0.94, \mathrm{NFI}=0.64$ vs 0.92 , $\mathrm{SRMR}=0.16$ vs 0.09 , RMSEA $=0.18$ vs $0.06, \mathrm{AIC}=357.40$ vs 122.46). As a result, the three-factor model was confirmed as the subscales of the QUALID-K scale in this study (Table 3).

\section{Validity}

Spearman's coefficient of correlation between the QUA LID-K score and the QoL-AD score showed a high value $(\mathrm{r}=-0.57, p<.001)$, suggesting an appropriate concurrent validity. As a result of the construct validity test, the MMSE-K $(\mathrm{r}=-0.21, p<.001)$, K-ADL $(\mathrm{r}=0.27, p<.001)$, $\operatorname{CSDD}(\mathrm{r}=0.54, p<.001)$ and FPS-R $(\mathrm{r}=0.36, p<.001)$ scores were correlated with the total score.

\section{Reliability}

The Cronbach's $\alpha$ coefficient of the QUALID-K scale was .81, indicating a high level of internal consistency. Item-total correlations, test-retest reliability, and interrater reliability are described in Table 4. 
Table 2. Factor Structures for the QUALID Scale

\begin{tabular}{lccc}
\hline Items & Factor 1 & Factor 2 & Factor 3 \\
\hline 6. Verbalizations suggest discomfort & .845 & & \\
\hline 7. Is irritable or aggressive & .802 & & .422 \\
\hline 5. Appears physically uncomfortable & .663 & .430 \\
\hline 4. Has facial expression of discomfort & .649 & .474 & .912 \\
\hline 11. Appears calm with others & .591 & .844 & .691 \\
\hline 10. Enjoys interacting with others & & & .711 \\
\hline 9. Enjoys touching/being touched & & & .701 \\
\hline 1. Smiles & & & .645 \\
\hline 8. Enjoys eating & & 22.1 & 17.8 \\
\hline 2. Appears sad & & 47.2 & 64.9 \\
\hline 3. Cries & 25.1 & & \\
\hline Explained variance (\%) \\
Cumulative variance (\%)
\end{tabular}

QUALID=Quality of life in late-stage dementia.

Table 3. Goodness-of-Fit Indexes in the Measurement Model

\begin{tabular}{lccccc}
\hline Model fit summary & $x^{2} / \mathrm{df}$ & GFI & NFI & SRMR & RMSEA \\
\hline$x^{2}=66.46, \mathrm{df}=38, p=.003$ & 1.75 & 0.94 & 0.92 & 0.09 & 0.06 \\
\hline
\end{tabular}

$\mathrm{df}=$ degrees of freedom; GFI=goodness-of-fit index; NFI=normed fit index; RMSEA=root mean square error of approximation;

$\mathrm{RMR}=$ standardized root mean square residual.

\section{DISCUSSION}

This study is the first trial to examine the psychometric properties of the QUALID-K scale. It is critical to apply cross-culturally reliable and validated scales for evaluating QoL, because it can vary according to cultural and social factors. The current study shows that the factorial structure of the QUALID-K scale is well suited to the data and that other values related to validity and reliability show good to excellent values. Overall, the study's validation results were similar to those found by previous studies of the original and several other versions of the QUALID scale in terms of the psychometric features dealt with in this study.

Concerning factorial structure, however, some differences were observed. In this study, the three-factor model of the QUALID-K scale was confirmed based on the result of PCA and CFA. Similarly, except for two studies, including the original English version [10], the majority of previous studies reported the three-factor model [23-26]. Although the individual items of each factor were not exactly the same, they commonly reported following items for each factor corresponding to this study: items 5, 6, 7, and 11 for factor 1 (except for the Italian version), items 1 , 9, and 10 for factor 2 (except for the Czech version) and items 2 and 3 for factor 3 (except for the Italian version).

These minor differing results regarding dimensionality might be due to the fact that these studies used only PCA and did not confirm the model by CFA and that the original QUALID scale was designed for late-stage dementia. In particular, the Italian and Czech language validation studies, which showed different factor loading with other studies, recruited relatively younger patients without dementia who were disabled (mean age: 56.6 years) and patients who were cognitively impaired with advanced illness (mean age: 76.1 years), respectively [23,24]. Therefore, each factorial model obtained might be applied according to the target population.

The QUALID-K scale was evaluated to have good internal consistency (Cronbach's $\alpha=.805$ ). Similarly, the previous validation studies reported a Cronbach's $\alpha$ of the QUALID scale as .77 in the original study, 0.68 in Japanese, 0.81 in Czech, and 0.74 in Swedish, Spanish, and Norwegian. The inter-rater reliability (Intra-class correlation coefficient $[\mathrm{ICC}]=0.913$ ) and test-retest reliability $(\mathrm{ICC}=0.866)$ of the QUALID-K scale were also evaluated 
Table 4. Item Analysis for the QUALID Scale

\begin{tabular}{llccc}
\hline Items & $\mathrm{M} \pm \mathrm{SD}$ & $\begin{array}{c}\text { Inter-rater } \\
\text { ICC }\end{array}$ & $\begin{array}{c}\text { Test-retest } \\
\text { ICC }\end{array}$ & $\begin{array}{c}\text { Correlation } \\
\text { item-total }\end{array}$ \\
\hline 1. Smiles & $3.31 \pm 1.48$ & $.850^{* * *}$ & $.894^{* * *}$ & $.582^{* * *}$ \\
\hline 2. Appears sad & $2.26 \pm 1.46$ & $.652^{* *}$ & $.687^{* * *}$ & $.531^{* * *}$ \\
\hline 3. Cries & $1.18 \pm 0.64$ & $.806^{* * *}$ & $.844^{* * *}$ & $.340^{* * *}$ \\
\hline 4. Has facial expression of discomfort & $2.59 \pm 1.12$ & $.582^{* *}$ & $.624^{* *}$ & $.756^{* * *}$ \\
\hline 5. Appears physically uncomfortable & $2.45 \pm 1.04$ & $.721^{* * *}$ & $.769^{* * *}$ & $.683^{* * *}$ \\
\hline 6. Verbalizations suggest discomfort & $2.71 \pm 1.35$ & $.612^{* *}$ & $.810^{* * *}$ & $.619^{* * *}$ \\
\hline 7. Is irritable or aggressive & $2.39 \pm 1.35$ & $.481^{*}$ & $.930^{* * *}$ & $.574^{* * *}$ \\
\hline 8. Enjoys eating & $1.77 \pm 1.30$ & $.729^{* * *}$ & $.676^{* * *}$ & $.343^{* * *}$ \\
\hline 9. Enjoys touching/being touched & $3.34 \pm 0.92$ & $.683^{* * *}$ & $.865^{* * *}$ & $.511^{* * *}$ \\
\hline 10. Enjoys interacting with others & $3.32 \pm 1.14$ & $.863^{* * *}$ & $.852^{* * *}$ & $.564^{* * *}$ \\
\hline 11. Appears calm with others & $2.96 \pm 1.10$ & $.813^{* * *}$ & $.899^{* * *}$ & $.805^{* * *}$ \\
\hline Total & $28.3 \pm 7.73$ & $.866^{* * *}$ & $.913^{* * *}$ & \\
\hline
\end{tabular}

${ }^{*} p<.05,{ }^{* *} p<.01,{ }^{* * *} p<.001$; ICC=Intra-class correlation coefficient; M=mean; QUALID=Quality of Life in Late-stage Dementia; SD=Standard deviation.

good to excellent in this study, similar to other versions of the QUALID scale [10,23,25-29].

The QUAID-K scale showed good intercorrelation with all included scales, on the basis of the three dimensions of QoL ("psychiatric symptoms", "meaningful activities", and "medical issues") in severe dementia proposed by Volicer and Bloom-Charette [8]. Firstly, regarding "Psychiatric symptoms", MMSE (cognitive function) and CSDD (depressive symptoms) scores were correlated with the QUALID score in this study. The low and negative correlation between MMSE and QUALID scores in the current study $(\mathrm{r}=-.21, p<.001)$ is similar to the results of Weiner et al. $(\mathrm{r}=-.20)$, Falk et al. $(\mathrm{r}=-.30)$, Garre-Olmo et al. $(r=-.30)$, and Nagata et al. $(r=-.35)[10,25,27,28]$. As the impact of cognitive function on QoL in dementia is still controversial, further investigation is needed in this area.

Concerning depression, Weiner et al. found a low and positive correlation $(\mathrm{r}=.36)$ between the QUALID scores and depression rated by the Geriatric Depression Scale (GDS)[10]. However, other studies that used proxy-based scales, such as the CSDD and the Patient Mood Assessment Scale (PMAS), for evaluating depression showed a moderate and positive correlation with QUALID scores $(\mathrm{r}>.5)$, except for Nagata et al.'s study $(\mathrm{r}=.26)$ [28]. The difference may result from the number of patients, which was more than two times greater in Røen et al. and Falk et al. than in Nagata et al. (197 and 169 vs. 70) [27-29]. Furthermore, the patients in the Nagata et al. study were older (87.4 years) and more likely to be cognitively impaired (mean score of MMSE $=5.44$ ) than in Falk et al. (86 years, MMSE=10.0), Røen et al. (84.9 years, MMSE=14.0) and the present study (83.6 years, MMSE=9.38) [27-29]. These findings may be explained by depression being associated with lower QoL in mild dementia to moderate dementia, while in severe dementia there is less consistency in the relationship [30].

With regard to "meaningful activity" and "medical issues," the K-ADL (functional status for basic ADL) and FPS-R (pain) scores showed significant correlations with the QUALID-K scores. In previous studies, as in this study, the QUALID scores were significantly correlated with ADL relatively low $(\mathrm{r}<.3)$, and with pain moderately ( $\mathrm{r}$ values around .5) $[25,28]$. Regarding ADL, Volicer and Bloom-Charette described the "meaningful activity" of people with dementia as an individual's preference for activities based on their own history [8]. Lawton defined "behavioral competence" as an ability to function in socially appropriate ways [7]. This study applied the K$\mathrm{ADL}$, which evaluates the functional status for basic ADL rather than activities reflecting a patient's history or his or her ability to function in socially appropriate ways. However, no one to the best of our knowledge has developed ADL measures reflecting those personal and social aspects, and such instruments would be needed for a better fit with the QoL in severe dementia.

Overall, the QUALID-K scale has shown the good to excellent psychometric features in line with the previous studies. On the basis of the study, therefore, QUALID-K 
scale can be considered a validated and reliable scale to evaluate the QoL of patients with dementia.

\section{Limitations}

Certain limitations of this study should be considered. First, the participants of this study were recruited from two long-term care hospitals during the observed period, and the sample size was relatively small. Therefore, the generalizability of the study results might be interpreted conservatively. However, in this study, because there were high loading values of the factors, the quality of the results could be considered high enough despite the small sample sizes. Second, as in most previous studies that validated the scale [10,23,27-29], This study included patients with dementia at all stages to reflect the practice in which applying the QUALID-K to patients with all stages of dementia is more practical than to only those with severe dementia. Thus, we propose a repetitive study targeted to the patients with severe dementia for a more in-depth understanding. Third, since this study was based on a cross-sectional design, the score changes of items with longitudinal designs should be measured.

\section{CONCLUSION}

The QUALID-K scale appears to be a useful measurement for assessing the Korean population's QoL in dementia. Overall, the results of this study could contribute to the extended availability of QUALID scale and a better understanding of QoL in severe dementia, and give an opportunity to compare and utilize the QoL indicators and related research results worldwide. Moreover, it could also be expected to be used as a basis for development of support systems and evidence-based interventions tailored for individuals with dementia and their families.

\section{CONFLICTS OF INTEREST}

The authors declared no conflict of interest.

\section{AUTHORSHIP}

Study conception and design acquisition - CSO; Data collection JE, PMS, LY-N and CSO; Analysis and interpretation of the data JE and CSO; Drafting and critical revision of the manuscript - JE and CSO; Final Approval - CSO.

\section{ACKNOWLEDGEMENT}

This research was supported by Basic Science Research Program through the National Research Foundation of Korea (NRF) fund- ed by the Ministry of Education, Science and Technology (NRF2017R1A2B4007896)(NRF-2019R1A2C1086122).

\section{REFERENCES}

1. World Health Organization. Dementia: a public health priority [Internet]. Geneva: World Health Organization; 2015 [updated 2015; cited 2019 Nov 29] Available from:

https://www.who.int/mental_health/neurology/dementia /dementia_thematicbrief_executivesummary.pdf

2. Perneczky R, Wagenpfeil S, Komossa K, Grimmer T, Diehl J, Kurz A. Mapping scores onto stages: mini-mental state examination and clinical dementia rating. The American journal of geriatric psychiatry. 2006;14(2):139-44. https://doi.org/10.1097/01.JGP.0000192478.82189.a8

3. Hughes S, Woods B, Algar-Skaife K, Jones CH. Understanding quality of life and well-being for people living with advanced dementia. Nursing Older People. 2020;33(1). https://doi.org/10.7748/nop.2019.e1129

4. WHOQOL group. The world health organization quality of life assessment (WHOQOL): position paper from the world health organization. Social Science \& Medicine. 1995;41(10): 1403-9. https:// doi.org/10.1016/0277-9536(95)00112-k

5. Whitehouse PJ, Orgogozo J-M, Dal-Bianco P, Becker R, Gathier S. Quality-of-life assessment in dementia drug development: position paper from the international working group on harmonization of dementia drug guidelines. Alzheimer Disease and Associated Disorders. 1997;11:56-60.

6. Bowling A, Rowe G, Adams S, Sands P, Samsi K, Crane M, et al. Quality of life in dementia: a systematically conducted narrative review of dementia-specific measurement scales. Aging \& Mental Health. 2015;19(1):13-31. https://doi.org/10.1080/13607863.2014.915923

7. Lawton MP. Quality of life in Alzheimer disease. Alzheimer Disease and Associated Disorders. 1994;8:138-50.

https://doi.org/10.1097/00002093-199424004-00015

8. Volicer L, Bloom-Charette L. Enhancing the quality of life in advanced dementia. New York (NY): Routledge; 1999. p. 6-20. https://doi.org/10.4324/9780203766347

9. Robertson S, Cooper C, Hoe J, Hamilton O, Stringer A, Livingston G. Proxy rated quality of life of care home residents with dementia: a systematic review. International Psychogeriatrics. 2017;29(4):569-81.

https://doi.org/10.1017/s1041610216002167

10. Weiner MF, Martin-Cook K, Svetlik DA, Saine K, Foster B, Fontaine $\mathrm{C}$. The quality of life in late-stage dementia (QUALID) scale. Journal of the American Medical Directors Association. 2000;1(3):114-6. https://doi.org/10.1037/t00432-000

11. Sopina E, Chenoweth L, Luckett T, Agar M, Luscombe GM, Davidson PM, et al. Health-related quality of life in people 
with advanced dementia: a comparison of EQ-5D-5L and QUALID instruments. Quality of Life Research. 2019;28(1): 121-9. https://doi.org/10.1007/s11136-018-1987-0

12. Black BS, Rabins PV. Dementia. 5th ed. Boca Raton (FL): CRC Press; 2017. p. 325-338. https://doi.org/10.1201/9781315381572

13. Comrey A, Lee H. A first course in factor analysis. 2nd ed. Hillsdale (NJ): Lawrence Earlbaum Associates; 1992. p. 299-325.

14. Costello AB, Osborne J. Best practices in exploratory factor analysis: four recommendations for getting the most from your analysis. Practical Assessment, Research, and Evaluation. 2005; 10(1):1-9. https:// doi.org/10.7275/jyj1-4868

15. Logsdon RG, Gibbons LE, McCurry SM, Teri L. Assessing quality of life in older adults with cognitive impairment. Psychosomatic Medicine. 2002;64(3):510-9. https://doi.org/10.1097/00006842-200205000-00016

16. Park J, Kwon Y. Standardization of Korean version of minimental state examination (MMSE-K) for use in the elderly: part II. diagnosis validity. Journal of the Korean Neuropsychiatric Association. 1989;28(3):508-13.

17. Folstein MF, Folstein SE, McHugh PR. "Mini-mental state": a practical method for grading the cognitive state of patients for the clinician. Journal of Psychiatric Research. 1975;12(3):189-98.

18. Katz S, Ford AB, Moskowitz RW, Jackson BA, Jaffe MW. Studies of illness in the aged: the index of ADL: a standardized measure of biological and psychosocial function. Journal of the American Medical Association. 1963;185(12):914-9.

19. Alexopoulos GS, Abrams RC, Young RC, Shamoian CA. Cornell scale for depression in dementia. Biological Psychiatry. 1988;23(3):271-84.

20. Hicks CL, von Baeyer CL, Spafford PA, van Korlaar I, Goodenough $B$. The faces pain scale-revised: toward a common metric in pediatric pain measurement. Pain. 2001;93(2):173-83. https://doi.org/10.1016/s0304-3959(01)00314-1

21. Kline RB. Principles and practice of structural equation modeling. 3rd ed. New York (NY): Guilford Press; 2011. p. 262-99.

22. Schermelleh-Engel K, Moosbrugger H, Müller H. Evaluating the fit of structural equation models: tests of significance and descriptive goodness-of-fit measures. Methods of Psychological Research Online. 2003;8(2):23-74.

23. Bužgová R, Kozáková R, Sikorová L, Jarošová D. Measuring quality of life of cognitively impaired elderly inpatients in palliative care: psychometric properties of the QUALID and CILQ scales. Aging \& Mental Health. 2017;21(12):1287-93. https://doi.org/10.1080/13607863.2016.1220919

24. De Vreese L, Uberti M, Mantesso U, De Bastiani E, Weger E, Marangoni A, et al. Measuring quality of life in intellectually disabled persons with dementia with the Italian version of the quality of life in late-stage dementia (QUALID) scale. Journal of Alzheimer's Disease \& Parkinsonism. 2012;2(1):1-5.

https://doi.org/10.4172/2161-0460.1000104

25. Garre-Olmo J, Planas-Pujol X, López-Pousa S, Weiner MF, Turon-Estrada $\mathrm{A}$, Juvinyà $\mathrm{D}$, et al. Cross-cultural adaptation and psychometric validation of a Spanish version of the quality of life in late-stage dementia scale. Quality of Life Research. 2010;19(3):445-53.

https://doi.org/10.1007/s11136-010-9594-8

26. Mjørud M, Kirkevold M, Røsvik J, Engedal K. Principal component analysis of the Norwegian version of the quality of life in late-stage dementia scale. Dementia and Geriatric Cognitive Disorders. 2014;37(5-6):265-75. https://doi.org/10.1159/000356497

27. Falk H, Persson L-O, Wijk H. A psychometric evaluation of a Swedish version of the quality of life in late-stage dmentia (QUALID) scale. International Psychogeriatrics. 2007;19(6): 1040-50. https://doi.org/10.1017/s1041610207005777

28. Nagata Y, Tanaka H, Ishimaru D, Uematsu M, Naito Y, Nishikawa T. Development of the J apanese version of the Quality of life in late-stage dementia scale. Psychogeriatrics. 2018;18 (2):106-12. https://doi.org/10.1111/psyg.12290

29. Røen I, Selbæk G, Kirkevold Ø, Engedal K, Lerdal A, Bergh S. The reliability and validity of the Norwegian version of the quality of life in late-stage dementia scale. Dementia and Geriatric Cognitive Disorders. 2015;40(3-4):233-42. https://doi.org/10.1159/000437093

30. Banerjee S, Samsi K, Petrie CD, Alvir J, Treglia M, Schwam $\mathrm{EM}$, et al. What do we know about quality of life in dementia? a review of the emerging evidence on the predictive and explanatory value of disease specific measures of health related quality of life in people with dementia. International Journal of Geriatric Psychiatry: A Journal of the Psychiatry of Late Life and Allied Sciences. 2009;24(1):15-24.

https://doi.org/10.1002/gps.2090 
Appendix 1. Korean Version of the Quality of Life in Late-Stage Dementia (QUALID) Scale 말기 치매 삶의 질 척도 (QUALID)

대상자 성명:

정보제공자 성명:
대상자 연령:

대상자와 정보제공자의 관계:
날짜:

지난 1 주일 동안 대상자가 한 행동을 가장 잘 나타내는 항목 한 개를 선택해주십시오.

\begin{tabular}{|c|c|}
\hline $\begin{array}{l}\text { 웃는다 } \\
\text { 1. 매일 } 1 \text { 회 이상 자발적으롤 } \\
\text { 2. 매일 } 1 \text { 회 미만 자발적으로 } \\
\text { (* 매일 } 1 \text { 회 미만 }=2 \text { 일에 } 1 \text { 회 이하의 의미) } \\
\text { 3. 외부 자극에 대한 반응으롤만, 매일 } 1 \text { 회 이상 } \\
\text { 4. 외부 자극에 대한 반응으로만, 매일 } 1 \text { 회 미만 } \\
\text { 5. 거의 웃지 않음 }\end{array}$ & $\begin{array}{l}\text { 신체적으로 불편해 보인다 - 꿈틀대거나, 몸부림치거나, } \\
\text { 자주 자세를 바꾼다 } \\
\text { 1. 드물게, 또는 전혀 그렇지 않다. } \\
\text { 2. 매일 } 1 \text { 회 미만 } \\
\text { 3. 매일 } 1 \text { 회 이상 } \\
\text { 4. 매일 거의 반나절 } \\
\text { 5. 매일 거의 대부분 }\end{array}$ \\
\hline $\begin{array}{l}\text { 슬퍼보인다 } \\
\text { 1. 드물게, 또는 전혀 그렇지 않다. } \\
\text { 2. 외부 자극에 대한 반응으로만, 매일 } 1 \text { 회 미만 } \\
\text { 3. 외부 자극에 대한 반으ㅇㅡㅡ로만, 매일 } 1 \text { 회 이상 } \\
\text { 4. 명백한 이유 없이 매일 } 1 \text { 회 미만 } \\
\text { 5. 명백한 이유 없이 매일 } 1 \text { 회 이상 }\end{array}$ & $\begin{array}{l}\text { 불만이나 불행, 불편함을 나타내는 말을 하거나 소리를 } \\
\text { 낸다 (불편, 신음, 비명) } \\
\text { 1. 드물게, 또는 전혀 그렇지 않다. } \\
\text { 2. 외부 자극에 대한 반응으로만, 매일 } 1 \text { 회 미만 } \\
\text { ⒊ 외부 자극에 대한 반응으로만, 매일 } 1 \text { 회 이상 } \\
\text { - 이유 없이 매일 } 1 \text { 회 미만 } \\
\text { 5. 이유 없이 매일 } 1 \text { 회 이상 }\end{array}$ \\
\hline $\begin{array}{l}\text { 운다 } \\
\text { 1. 드물게, 또는 전혀 그렇지 않다. } \\
\text { 2. 외부 자극에 대한 반응으로만, 매일 } 1 \text { 회 미만 } \\
\text { 3. 외부 자극에 대한 반응으로만, 매일 } 1 \text { 회 이상 } \\
\text { 4. 명백한 이유 없이 매일 } 1 \text { 회 미만 } \\
\text { 5. 명백한 이유 없이 매일 } 1 \text { 회 이상 }\end{array}$ & 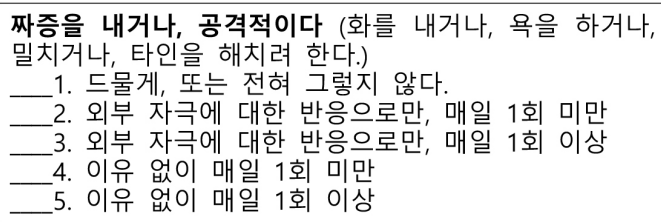 \\
\hline 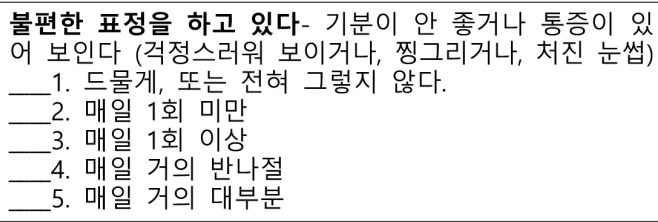 & $\begin{array}{l}\text { 먹는 것을 즐긴다 } \\
\text { 1. 대부분의 식사와 간식을 } \\
\text { 2. 매일 } 2 \text { 회 } \\
\text { 3. 매일 } 1 \text { 회 이상 } \\
\text { 4. 매일 } 1 \text { 회 미만 } \\
\text { 5. 드물게, 또는 전혀 그렇지 않다. }\end{array}$ \\
\hline $\begin{array}{l}\text { 접촉하기/접촉받기를 좋아한다 } \\
\text { 1. 거의 항상; 거의 항상 접촉을 시작한다. } \\
\text { 2. 절반 이상; 때때로 접족하기를 시작한다. } \\
\text { 3. 절반 정도; 결코 접촉하기를 시작하지는 않지만, } \\
\text { 접촉하기를 거부하지 않는다. } \\
\text { 4. 절반 미만; 종종 또는 자주 접촉하기/접촉받기를 } \\
\text { 거부한다. } \\
\text { 5. 드물게, 또는 전혀 그렇지 않은; 거의 항상 접촉 } \\
\text { 하기/접촉받기를 거부한다. }\end{array}$ & $\begin{array}{l}\text { 타인과 상호작용하거나 함께 있는 것을 즐긴다 } \\
\text { 1. 거의 항상; 거의 항상 타인과 상호작용을 시작한 } \\
\text { 다. } \\
\text { 2. 절반 이상; 때때로 타인과 상호작용을 시작한다. } \\
\text { 3. 절반 정도; 결코 상호작용을 시작하지 않지만, 타 } \\
\text { 인과의 상호작용을 거부하지 않는다. } \\
\text { 4. 절반 미만; 타인과의 상호작용을 자주 거부한다. } \\
\text { 5. 드물게, 또는 전혀 그렇지 않음; 타인과의 상호작 } \\
\text { 용을 거의 함상 거부한다. }\end{array}$ \\
\hline $\begin{array}{l}\text { 정서적으로 안정되고 편안해 보인다 } \\
\text { 1. 매일 대부분 } \\
\text { 2. 매일 반나절 이상 } \\
\text { 3. 매일 반나절 } \\
\text { 4. 매일 반나절 미만 } \\
\text { 5. 드물게, 또는 전혀 그렇지 않다. } \\
\end{array}$ & \\
\hline ) 총점 (모든 항목들의 합계: 점수는 $11-55$ & 이며, 점수가 낮을수록 삶의 질이 높음을 나타낸다.) \\
\hline \multicolumn{2}{|l|}{ *아래항목은 점수에 미포함됩니다. } \\
\hline $\begin{array}{l}\text { 대상자에 대한 친숙도 및 돌봄제공자의 지식 } \\
0 \text { 매우 친숙함, 매일 돌볼을 제공함 } \\
1 \text { 다소 친숙함, 자주 약간의 돌봄을 제공함 } \\
2 \text { 별로 친숙하지 않음, 약만 추고 접촉은 최소한으로 함 }\end{array}$ & 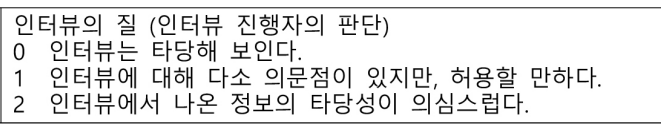 \\
\hline
\end{tabular}

